\title{
Titanium-based high-melting nanodispersed compositions obtaining and study
}

\author{
V.I.Bolshakov ${ }^{1}$, A.V.Kalinin ${ }^{1}$, D.B.Glushkova ${ }^{2}$, \\ I.G.Kirichenko' , A.I.Voronkov ${ }^{2}$, L.L.Kostina ${ }^{2}$ \\ ${ }^{1}$ Prydniprovska State Academy of Civil Engineering and Architecture, 24a \\ Chernishevskogo St., 49600 Dnipro, Ukraine \\ ${ }^{2}$ Kharkiv National Automobile and Highway University, 25 Yaroslava \\ Mudrogo St., 61002 Kharkiv, Ukraine
}

Received June 20, 2018

\begin{abstract}
Crystallographic characteristics of nanodispersed materials obtained by plasma-chemical synthesis were studied. Using industrial equipment for plasma-chemical synthesis the nanodispersed powders of high-melting carbide, nitride, carbonitride and silicide class compounds based on titanium, magnesium, aluminium, silicon were obtained. Technology for synthesis of powder fraction less than $100 \mathrm{~nm}$ was developed. The efficiency of nanodisperse compositions use in smelting of structural steels was determined. In the result of $10 \Gamma 2 \mathrm{C}$ steel modification with $\mathrm{Ti}(\mathrm{CN})$ nanopowder properties may by notice ably enhanced. Elemental composition of nanodispersed composition was determined: SiC, TiC, $\mathrm{TiN}, \mathrm{Ti}(\mathrm{CN})$, AIN, $\mathrm{Mg}_{2} \mathrm{Si}, \mathrm{Mg}_{3} \mathrm{~N}_{2}$. The elemental composition of synthesized compounds corresponded to stoichiometric composition. Microdiffractional patterns of the particles were analyzed; it was shown that nanopowders belong to the solid crystalline bodies with metallic bond. It has been found, that titanium carbonitride $\mathrm{Ti}(\mathrm{CN})$ particles have face-centered crystal lattice, while silicon carbide ( $\mathrm{SiC}$ ) particles have hexagonal lattice. Experiments for steel $10 \Gamma 2$ and $10 Г 2 \mathrm{C}$ modifying with nanopowder compositions on base of $\mathrm{Ti}(\mathrm{CN})$ and $\mathrm{SiC}$ were carried out. The efficiency of nanodisperse compositions use in smelting of structural steels was determined. In the result of $10 \Gamma 2 \mathrm{C}$ steel modification with $\mathrm{Ti}(\mathrm{CN})$ nanopowder strength, plastic properties and impact toughness were improved. The choice of nanodisperse titanium carbonitride $\mathrm{Ti}(\mathrm{CN})$ powders with $100 \mathrm{~nm}$ fraction for light alloy steels modifying was justified. The required criteria for choice of nanopowder modifiers were obtained: insolubility in smelt, correspondence of crystal lattice to steel matrix, commensurability with austenite germ critical radius in crystallizing.
\end{abstract}

Keywords: nanodispersed composition, modifying, plasma-chemical synthesis, structural steel, mechanical characteristics, crystallographic characteristics.

Исследованы особенности кристаллографических параметров нанодисперсных материалов плазмохимического синтеза. На промышленной установке плазмохимического синтеза получены нанодисперсные порошки тугоплавких соединений карбидного, нитридного, карбонитридного и силицидного класса на основе титана, магния, алюминия, кремния. Отработана технология синтеза порошков фракции менее 100 нм. Установлена әффективность применения нанодисперсных композиций при выплавке конструкционных сталей. В результате модифицирования стали 10 Г2С нанопорошком $\mathrm{Ti}(\mathrm{CN})$ могут быть заметно повышены свойства. Определён химический состав нанодисперсных композиций: $\mathrm{SiC}, \mathrm{TiC}, \mathrm{TiN}, \mathrm{Ti}(\mathrm{CN}), \mathrm{AIN}, \mathrm{Mg}_{2} \mathrm{Si}, \mathrm{Mg}_{3} \mathrm{~N}_{2}$. Химический состав синтезированных соединений соответствовал стехиометрическому составу. Проведен анализ микродифракционных картин частиц, показана принадлежность нанопорошков $к$ твердым кристаллическим телам с металлической связью. Установлено, что частицы карбонитрида титана $\mathrm{Ti}(\mathrm{CN})$ имеют гранецентрированную, а карбида кремния (SiC) - гексагональную кристаллическую решетку. Проведены эксперименты по модифицированию 
сталей 10Г2, 10Г2C нанопорошковыми композициями на основе $\mathrm{Ti}(\mathrm{CN})$ и $\mathrm{SiC}$. Обоснован выбор нанодисперсных порошков карбонитрида титана Ti(CN) фракции менее 100 нм в качестве модификаторов низколегированных сталей. Получены необходимые критерии выбора нанопорошковых модификаторов: нерастворимость в расплаве, соответствие кристаллических решёток с матрицей стали, соразмерность с критическим радиусом зародыша аустенита при кристаллизации.

Отримання та дослідження властивостей тугоплавких нанодисперсних композицій на основі титану. В.І.Большаков, А.В.Калінін, Д.В.Глушкова, І.Г.Кириченко, А.І.Воронков, Л.Л.Костіна.

Досліджено особливості кристалографічних параметрів нанодисперсних матеріалів плазмохімічного синтезу. На промисловій установці плазмохімічного синтезу отримано нанодисперсні порошки тугоплавких сполук карбідного, нітридного, карбонітридного та силіцидного класів на основі титану, магнію, алюмінію, кремнію. Відпрацьовано технологію синтезу порошків фракції менше 100 нм. Встановлено ефективність застосування нанодисперсних композицій при виплавці конструкційних сталей. У результаті модифікування сталі 10Г2C нанопорошком $\mathrm{Ti}(\mathrm{CN})$ можуть бути помітно підвищені властивості. Визначено хімічний склад нанодисперсних композицій: SiC, TiC, TiN, $\mathrm{Ti}(\mathrm{CN})$, AIN, $\mathrm{Mg}_{2} \mathrm{Si}, \mathrm{Mg}_{2} \mathrm{~N}_{2}$. Хімічний склад синтезованих сполук відповідає стехіометричному складу. Проведено аналіз мікродифракційних картин частинок, показана належність нанопорошків до твердих кристалічних тіл з металевим зв'язком. Встановлено, що частинки карбонітриду титану $\mathrm{Ti}(\mathrm{CN})$ мають гранецентровану, а карбіду кремнію (SiC) - гексагональну кристалічну решітку. Проведено експерименти 3 модифікування сталей $10 Г 2,10 Г 2 \mathrm{C}$ нанопорошковими композиціями на основі $\mathrm{Ti}(\mathrm{CN}) \mathrm{i}$ $\mathrm{SiC}$. Обгрунтовано вибір нанодисперсних порошків карбонітриду титану Ti(CN) фракції менше 100 нм в якості модифікаторів низьколегованих сталей. Отримано необхідні критерії вибору нанопорошкових модифікаторів: нерозчинність у розплаві, відповідність кристалічних решіток з матрицею сталі, співмірність з критичним радіусом зародка аустеніту при кристалізації.

\section{Introduction}

The problem of manufacturing of tailormade products (wear-resisting, hot-resistance, corrosion-resistant) for industry is connected with steel alloying by deficit metals: Mo, V, rare-learth metals, Nb [1]. Constructional nanostructural materials take a special place between materials with specific structure and characteristics [3, 4, 6-8].The use of large particles-modifiers more than $10 \mu \mathrm{m}$ size in steelmaking is well studied [1]. One of the prior tendencies in the modern materials science development is nanomaterials and nanotechnologies. The use of nanodispersed particles for steel structure management is studied just in few works. Thus, in modifying [9] of low-alloyed steel by high-melting compositions, it has been detected the formation of dispersed structures with homogeneous distribution of strengthening phases. However, it should be noted, that work doesn't have thermodynamic analysis of parameters of modifying processes in smelting crystallization. That means that there are difficulties from practical point of view in choosing of optimal composition content and size range of used nanocompounds. It is connected with surface phenomena essential changes on the "modifier-smelt" boundary and thermody- namic process parameters changes because of nanoparticles addition.

To solve this problem the estimation [5] of nanoparticles action efficiency during the smelt's treatment was done. The dependence of modifier solubility degree in smelt on thermodynamic stability of process and difference of nanoparticles and smelt melt temperature were defined. Despite of practical value of presented data, features of nanocompositions crystallographic structure were not studied.

The purpose of work was to study a problem of obtaining high-melting nanodispersed compositions with tailor-made crystallographic parameters for structural steels modifying.

To reach the purpose the following objectives were solved:

- to obtain nanodispersed compositions of carbide, nitride and carbonitride classes with particles size less than $100 \mathrm{~nm}$ using plasmachemical synthesis industrial equipment;

- to define elemental composition, physical characteristics and crystallographic nanoparticles parameters;

- to conduct experimental-industrial $10 \Gamma 2$ and $10 Г 2 \mathrm{C}$ steels smelting with use of nanomodifiers;

- to define the influence of tailor-made crystallographic nanoparticles parameters on complex of structural steels mechanical characteristics. 
V.I.Bolshakov et al. / Titanium-based high-melting ...

Table 1. Elemental composition of synthesized nanodispersed compounds

\begin{tabular}{||c|c|c|c|c|c|c|c|c|c|c||}
\hline \multirow{2}{*}{ Material } & \multicolumn{10}{|c||}{ Element content, wt. \%. } \\
\cline { 2 - 10 } & $\mathrm{Si}$ & Si free & $\mathrm{C}$ & $\mathrm{C}$ free & $\mathrm{N}$ & $\mathrm{Al}$ & $\mathrm{Al}$ free & $\mathrm{Ti}$ & $\mathrm{Ti}$ free & $\mathrm{Mg}$ \\
\hline $\mathrm{SiC}$ & 65 & 2.0 & 30 & 2.0 & 1.0 & - & - & - & - & - \\
$\mathrm{AIN}$ & - & - & - & 0.5 & 33 & 65 & 1.5 & - & - & - \\
$\mathrm{TiC}$ & - & - & 21 & 1.5 & - & - & - & 76 & 1.5 & - \\
$\mathrm{TiN}$ & - & - & - & 1.0 & 23 & - & - & 75 & 1.0 & - \\
$\mathrm{Ti}(\mathrm{CN})$ & - & - & 15 & 1.0 & 19 & - & - & 65 & 1.0 & - \\
$\mathrm{Mg}_{2} \mathrm{Si}$ & 33 & 1.0 & - & - & 1.0 & - & - & - & - & 65 \\
\hline
\end{tabular}

\section{Experimental}

Modifying was conducted on constructional low-alloyed $10 \Gamma 2$ and $10 \Gamma 2 \mathrm{C}$ steels with use of nanodispersed modifiers: TiC, $\mathrm{TiN}, \mathrm{Ti}(\mathrm{CN}), \mathrm{SiC}, \mathrm{AIN}, \mathrm{Mg}_{2} \mathrm{Si}$ with particles size 20...100 $\mathrm{nm}$. Modifiers were produced in Neomat JSC (Latvia) at high-frequency industrial equipment for plasma-chemical synthesis AEROXIDEP-25.

To generate plasma the vortex induction plasma torch with gas discharge stabilization was used. Initial materials were gradually injected in nitric plasma flow with temperature $5500-7500^{\circ} \mathrm{C}$. Heating, melting, evaporation of the injected materials and their chemical interaction were conducted [2].

The study of size and crystallographic structure of nanocompositions was conducted with use of transmission electron microscope $3 \mathrm{M}-125$ at 100000 times magnification and X-ray diffractometer DRON 2.0 with $\mathrm{Cu}$-anode.

Smelting and modifying of steels were done in industrial induction furnace with capacity $200 \mathrm{~kg}$ at temperature $1600^{\circ} \mathrm{C}$. Mechanical pull testing was done on standard samples according to GOST 1497-84. The impact toughness was determined by GOST 9454-80.

As key parameters of mechanical characteristics the following were selected: resistance to rupture, flow limit, percentage extension, contraction ratio, impact hardness. The key parameters of nanocompositions were: physical characteristics, specific surface area, and crystalline lattice distance.

\section{Results and discussion}

Elemental composition of nanodispersed compositions obtained at plasma-chemical synthesis industrial equipment is shown in Table 1. It should be mentioned, that in the base of all compositions are elements (Al, Ti, $\mathrm{Mg}$, forming chemical compounds. The content of those elements in unbound state can reach $20 \%$. Character of size-distribution of

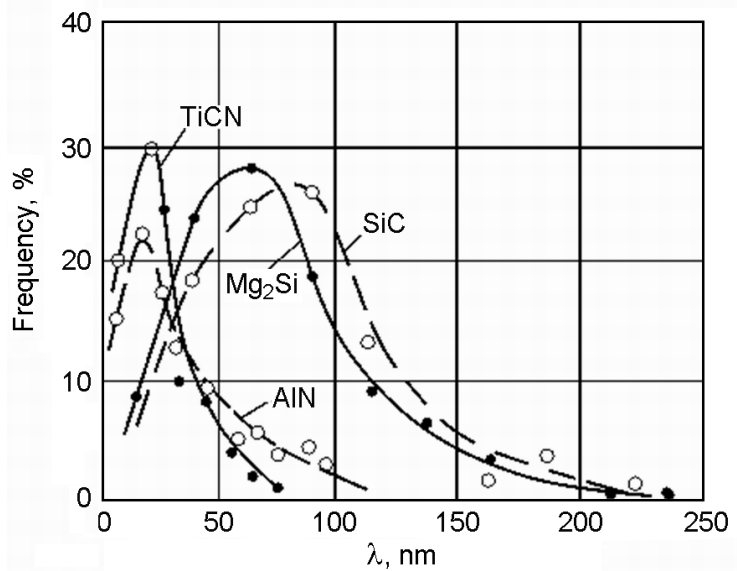

Fig. 1. Distribution charts of nanoparticles $\mathrm{Ti}(\mathrm{CN})$, AIN, SiC, $\mathrm{Mg}_{2} \mathrm{Si}$.

nanoparticles compounds of plasma-chemical synthesis is shown on Fig. 1. It should be noticed that the smallest range of size-distribution has $\mathrm{Ti}(\mathrm{CN})(10 . .70 \mathrm{~nm})$, and the biggest one - SiC $(10 \ldots 250 \mathrm{~nm})$. Obtained data let us conclude that character of particles size-distribution is asymmetrical. $\mathrm{Ti}(\mathrm{CN})$ particles with biggest density (see Table 2) have average size less than $100 \mathrm{~nm}$, and more light particles (AIN and $\mathrm{SiC}$ ) have bigger size up to $200 \mathrm{~nm}$.

Summarized data of crystallographic and physical characteristics studies of nanodispersed materials is shown in Table 2. Analysis of powders crystallographic characteristics, particles electron microscopic images and their microdiffraction patterns show that finely dispersed composition artificially created with plasma-chemical synthesis belongs to solid crystalline compounds (Fig. 2). SiC, Ti(CN) saved their ability for self-faceting and represent discrete three-dimensional system. The ability of synthesized systems for self-faceting is a consequence of their internal crystallographic structure due to which atoms of crystal-particles are located on certain crystallite lines and planes. This contributed to 
Table 2. Crystallographic and physical characteristics of nanocompositions.

\begin{tabular}{|c|c|c|c|c|c|c|c|}
\hline \multirow[t]{2}{*}{$\begin{array}{l}\text { Mate- } \\
\text { rial }\end{array}$} & \multirow[t]{2}{*}{$\begin{array}{l}\text { Crystal } \\
\text { lattice }\end{array}$} & \multirow[t]{2}{*}{ Phase type } & \multicolumn{2}{|c|}{$\begin{array}{c}\text { Lattice } \\
\text { distance, } \AA\end{array}$} & \multirow[t]{2}{*}{$\begin{array}{l}\text { Density, } \\
\mathrm{kg} / \mathrm{m}^{3}\end{array}$} & \multirow[t]{2}{*}{$\begin{array}{l}\text { Melting temperature } \\
\text { (decomposition), }{ }^{\circ} \mathrm{C} \text {. }\end{array}$} & \multirow{2}{*}{$\begin{array}{c}\text { Estimated } \\
\text { specific } \\
\text { surface area } \\
\mathrm{m}^{2} / \mathrm{gm}^{3}\end{array}$} \\
\hline & & & $\mathrm{a}$ & c & & & \\
\hline $\mathrm{SiC}$ & $\begin{array}{c}\text { Hexagonal, } \\
\text { trigonal }\end{array}$ & Implementation & 3.080 & 10.04 & 3220 & 2830 Decomposition & 54.8 \\
\hline AIN & Hexagonal & Implementation & - & - & 2350 & 2200 Melting & 64.6 \\
\hline $\mathrm{TiC}$ & Cubic & Implementation & 4.319 & - & 4920 & 3140 Melting & 24.7 \\
\hline TiN & Cubic & Implementation & 4.243 & - & 5430 & 2950 Melting & 21.6 \\
\hline $\mathrm{Ti}(\mathrm{CN})$ & Cubic & Implementation & 4.256 & - & 4950 & 3120 Melting & 44.0 \\
\hline $\mathrm{Mg}_{2} \mathrm{Si}$ & $\begin{array}{l}\text { Cubic, } \\
\text { spheric }\end{array}$ & Substitution & 6.338 & - & 2920 & 1170 Decomposition & 42.8 \\
\hline
\end{tabular}

plasma gas volume condensation during plasma-chemical synthesis, which allows particles to have free crystallizing surface, which is confirmed in studies [10-12].

Analysis of microdiffraction patterns of silicon carbide crystals allowed to define, that by crystalline structure they belongs to hexagonal syngony with $a=3.08 \AA, c=$ $10.04 \AA$ parameters. SiC particles are forming in shape of hexagonal and trigonal prisms with low height (Fig. 2a, b). Analysis of contrast on SiC particle image demonstrates that it has smaller size on the periphery than in central part.

From theoretical point of view it can be considered that particles faceting is tending to provide maximum surface energy with their minimal sizes.

Electron microscopy $\mathrm{Ti}(\mathrm{CN})$ particles analysis has shown, that particles have facecentered cubic lattice with $a=4,25 \AA$ parameter. This is consistent with the data for $\operatorname{TiC}(a=4.319 \AA)$ and $\operatorname{TiN}(a=4.243 \AA)$ [13].

Comparing of measured and pre-calculated interplane $\mathrm{Ti}(\mathrm{CN})$ distance on diffraction patterns showed that $\mathrm{Ti}(\mathrm{CN})$ lattice is built on base of titanium carbide TiC, nitrogen atoms are in octahedral interstitial sites forming solid solution of nitrogen substitution in titanium carbide crystal lattice.

According to it $\mathrm{Ti}(\mathrm{CN})$ particles are formed of cube or tetragons. This is indicated by crystals projections configurations during their orientation [001], [111], [110]. Distinct linearity of cubes projections sides is pointing on high $\mathrm{Ti}(\mathrm{CN})$ faces and edges perfection. Obtained data are consistent with studies data $[13,14]$.

Electron microscopic images of magnesium silicide $\mathrm{Mg}_{2} \mathrm{Si}$ particles are showing non-spherical form of particles in face-cen-
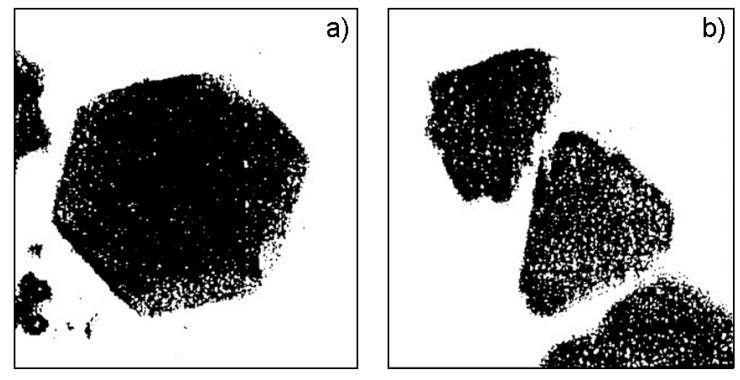

Fig. 2. Electron microscopic images of ultradispersed silicon carbide particles, $\times 100000$. Prisms: a) hexagonal, b) trigonal.

tered cubic lattice. There are different opinions about $\mathrm{Mg}_{2} \mathrm{Si}$ crystalline lattice type. According to the obtained data [15] $\mathrm{Mg}_{2} \mathrm{Si}$ crystalline lattice is hexagonal.

Our calculations results shows that $\mathrm{Mg}_{2} \mathrm{Si}$ interplane distances correspond to face-centered cubic lattice with $a=6.338 \AA$ parameter (Table 2).

It is mentioned in $[10-13,16]$, that plasma-chemical nanodispersed powders obtaining is due to high rate of gas-fired flow volume condensation, which leads to nanodispersed particles unstable state.

The effective way to create finely dispersed structure and high complex of mechanical characteristics of structural steels is to modify smelts with high-melting nanodispersed compositions on base of titanium $[2,5,11]$. The titanium carbonitride $\mathrm{Ti}(\mathrm{CN})$ with 20-50 nm particles size is the most effective modifier. This high-melting composition has face-centered cubic lattice like austenite face-centered cubic lattice and promotes the formation of dispersed structure of structural steels.

Mechanical characteristics of samples cut from deformed rods, after thermo-harden- 
V.I.Bolshakov et al. / Titanium-based high-melting ...

Table 3. Modification influence on mechanical characteristics of $10 \Gamma 2$ and $10 Г 2 \mathrm{C}$ steels

\begin{tabular}{||c|c|c|c|c|c|c||}
\hline \multirow{2}{*}{ Steel brand } & \multirow{2}{*}{ Steel state } & \multicolumn{5}{|c||}{ Mechanical characteristics } \\
\cline { 3 - 7 } & & $\sigma_{v}, \mathrm{MPa}$ & $\sigma_{0.2}, \mathrm{MPa}$ & $\delta, \%$ & $\psi, \%$ & $\mathrm{KCU}, \mathrm{MJ} / \mathrm{m}^{2}$ \\
\hline 10Г2 & Unmodified & 574 & 512 & 19.0 & 40.6 & 0.58 \\
$10 Г 2$ & Modified & 762 & 641 & 21.5 & 45.2 & 0.76 \\
10Г2C & Unmodified & 657 & 568 & 18.2 & 43.0 & 0.58 \\
10Г2C & Modified & 811 & 675 & 22.4 & 45.7 & 0.81 \\
\hline
\end{tabular}

ing treatment of experimental-industrial batches of $10 \Gamma 2$ and $10 \Gamma 2 \mathrm{C}$ steels and after modifying are given in Table 3.

By revising of mechanical tests data set it was defined that in result of modifying with nanodispersed $\mathrm{Ti}(\mathrm{CN})$, strength and plastic steels characteristics are increasing: $\sigma_{v}$ and $\sigma_{0.2}$ average increase is $20 \% ; \delta-$ $23 \% ; \psi-6 \%$. The most significant was the impact toughness increase averagely on $40 \%$ in comparison to unmodified state. That proves the efficiency of modifying.

\section{Conclusions}

Special aspects of crystallographic structure and physical characteristics of nanodispersed compositions of carbide, carbonitride and silicide classes which are in correspondence between nanoparticles crystal lattice and steel crystal lattice parameters were determined. Due to that it's possible to assert that nanodispersed titanium carbonitride $\mathrm{Ti}(\mathrm{CN})$ has the most effective influence on $10 \Gamma 2$ and $10 \Gamma 2 \mathrm{C}$ steels modifying process. This is manifested in the fact that $\mathrm{Ti}(\mathrm{CN})$ particles apparently serves as centers of crystallization allowing to obtain steel dispersed composition and thereby a high level of mechanical properties.

By analyzing structural steels mechanical characteristics data set it was defined that titanium carbonitride modifying increase strength and plastic characteristics averagely on $20 \%$; impact toughness has the biggest increase (on $40 \%$ ).

The efficiency of nanodispersed compositions use in industrial conditions production of structural steels with increased mechanical characteristics complex was determined.

\section{References}

1. V.I.Bolshakov, L.L.Dvorkin, Structure and Properties of Building Materials, Switzerland: TTP (2016).

2. L.P.Stafetskiy, Plazmennyy Sintez Nanoporoshkov v AO "NEOMAT", Sb. Dokladov Plazmennye Protsessy v Metallurgii i Obrabotke Metallov, IMet im. A.A.Baykova, Moscow (2016).

3. V.Kyryliv, O.Maksymov, O.Fesenko, L.Yatcenko, Nanocomposites, Nanophotonics, Nanobiotechnology and Aplications, Springer Inbunden (2014), p.31.

4. W.Barsoum, Max-Phases: Properties of Machinabletermary Carbides and Nitrides. John Willey and Sons, Weinheim (2013).

5. N.Ye.Kalinina, O.A.Kavats, V.T.Kalinin, Aviatsionno-kosmicheskaya Tekhnika i Tekhnologiya, No. 8, 41 (2007).

6. V.N.Naguib, M.W.Barsoum, Y.Gogotsy, $A d v$. Functional Mater., 26, 992 (2014).

7. Carbon Nanotube Electronics, ed. by A.Javey, J.Kong. Springer Science+Business Media, LLC (2009).

8. N.Tagmatarchis, Advances in Carbon Nanomaterials - Science and Applications, Pan Stanford Publishing (2011).

9. N.Tagmatarchis, Z Zhang, Front. Energy Power Engin. China, 3, 11 (2011).

10. J.Rodriguez, M.Garcia, Synthesis, Properties, and Applications of Oxide Nanomaterials, Wiley-Interscience, New York (2007).

11. D.Vollath, Nanomaterials: an Introduction to Synthesis, Properties and Application, WileyVCH, New York (2008).

12. Nanoparticle Technology Handbook, ed. by M.Hosokawa, K.Nogi, M.Naito, T.Yokoyama, Elsevier, Amsterdam (2007).

13. C.Kumar, Nanocomposites, Wiley-VCH, New York (2010).

14. Thermal Nanosystems and Nanomaterials, ed. by S.Volz, Springer-Verlag, Berlin Heidelberg (2009).

15. M.Faghri, B.Sunden, ed. by Southampton, WIT Press, Boston (2002). 